\title{
Production and Characterization of Keratinolytic Protease of Bacillus licheniformis MZK-03 Grown on Feather Mill
}

\author{
Debasish Paul, Alamgir Rahman, Mohammad Ilias and M Mozammel Hoq* \\ Department of Microbiology, University of Dhaka, Dhaka 1000, Bangladesh
}

[Received 07 April 2007; Accepted 21 April 2007]

\begin{abstract}
Keratinolytic protease is an inducible specific proteolytic enzyme, which is produced by Bacillus licheniformis MZK-03 in presence of keratin (feather mill) as sole carbon and nitrogen source in growth medium. Maximum level of keratinolytic protease was produced after $42 \mathrm{~h}$ at $37^{\circ} \mathrm{C}$ over a wide range of initial $\mathrm{pH}(5.0$ to 12.0) under continuous agitation $(200 \mathrm{rpm})$. Keratinolytic protease worked best at $37^{\circ} \mathrm{C}$ and at $\mathbf{p H} 8.5$. The enzyme was quite stable over a wide range of $\mathrm{pH}(7.0$ to 11.0$)$ but activity dropped drastically beyond this level (enzyme activity dropped to $8.8 \%$ and $19.3 \%$ at $\mathrm{pH} 6.5$ and 12.0 , respectively). Half-life of keratinolytic protease at $70^{\circ}$ and $60^{\circ} \mathrm{C}$ were found to be 3 and $7 \mathrm{~min}$ respectively. The enzyme showed highest stability at $40^{\circ} \mathrm{C}(>90 \%$ after $3 \mathrm{~h})$. The half-life at $4^{\circ} \mathrm{C}$ was 34 days. The presence of metal ions $(5 \mathrm{mM})$ like $\mathrm{Mg}^{2+}, \mathrm{Mn}^{2+}$, $\mathrm{Ca}^{2+}$ and $\mathrm{K}^{+}$had no remarkable effect on the keratinolytic protease activity but the activity decreased in presence of $\mathrm{Hg}^{2+}$ and $\mathrm{Cu}^{2+}$. The enzyme may belong to serine protease group as it is inhibited by serine protease inhibitor phenyl methyl sulphonyl fluoride (PMSF). The enzyme is as compatible as other commercially available enzymes used in leather industry with tannery chemicals. It was completely incompatible with $\mathrm{Na}_{2} \mathrm{~S}$ and $\mathrm{CaO}$ for their high alkalinity $(\mathrm{pH}>13.0)$, which was also observed for other commercial enzymes except the commercial enzyme supplemented with ammonium sulphate.
\end{abstract}

Keywords: Bacillus licheniformis MZK-03, Keratinolytic protease, Keratin, Production, Characterization

\section{Introduction}

Proteases are catabolic enzymes that catalyze the complete hydrolysis of protein. They constitute one of the most important groups of industrial enzymes, accounting for nearly $60 \%$ of the total worldwide enzyme sale ${ }^{1}$. Keratinolytic protease is a specific protease that has immense commercial importance. It acts on keratin of the hides thus can be used in dehairing 2 . This enzyme along with protease can be effectively used in leather industry as dehairing agent instead of chemicals or with chemicals thus reducing the use of harsh chemicals in leather processing. In addition, it offers considerable opportunities for a low-energy consuming technology for bioconversion of poultry feathers to protein enriched feedstuff for livestock $\mathrm{k}^{2-3}$.

Only few bacterial species have been reported till date able to produce keratin enzyme. Many of the Bacillus spp. are found to be useful in enzyme, amino acids, essential metabolites and life saving drug production ${ }^{4}$. Isolation of keratinolytic protease producing strains of Bacillus licheniformis were previously reported by us but elaborate characterization was not carried out ${ }^{5}$. One of the major drawbacks affecting the stability at alkaline $\mathrm{pH}$ of enzymes recovered from thermophiles is that enzymes from alkalophiles confer stability to a wide range of $\mathrm{pH}$ but are usually thermolabile 6 . In the present study we have optimized the physical conditions of keratinolytic protease production and partially characterized the keratinolytic protease produced by Bacillus licheniformis MZK-03.

\section{Materials and Methods}

Microorganism

Bacillus licheniformis strain MZK-03 was previously isolated from feather-decomposed soil and identified by 16S rRNA typing 5 . Stock culture of the organism was maintained at $-70^{\circ} \mathrm{C}$ in nutrient broth containing 10\% glycerol.

Production of seed culture

A single colony from a freshly subcultured nutrient agar plate was transferred into $250-\mathrm{ml}$ conical flask containing $50 \mathrm{ml}$ of nutrient broth. The flask was incubated for $6-10 \mathrm{~h}$ at $37^{\circ} \mathrm{C}$ and 200 rpm in an orbital shaker until it reached to an absorbance of 0.50.8 at $600 \mathrm{~nm}$.

Fermentation and separation of culture filtrates

The seed culture (5 ml) was transferred to $95 \mathrm{ml}$ of feather mill medium in a 500-ml Erlenmeyer flask. Feather mill medium contained 0.075\% NaCl, 0.21\% $\mathrm{K}_{2} \mathrm{HPO}_{4}, 0.105 \% \mathrm{KH}_{2} \mathrm{PO}_{4}, 0.015 \%$ $\mathrm{MgCl}_{2} \cdot 6 \mathrm{H}_{2} \mathrm{O}, 0.009 \% \mathrm{CaCl}_{2}, 0.15 \%$ molasses and $0.75 \%$ feather mill (initial pH 7.5). The inoculated flasks were placed in a thermostated orbital shaker for $48 \mathrm{~h}$, at $37^{\circ} \mathrm{C}$ and $150 \mathrm{rpm}$. Samples were withdrawn at regular intervals and centrifuged at 5,000 rpm for $20 \mathrm{~min}$. The cell free supernatant was preserved at $4^{\circ} \mathrm{C}$ and used for enzyme assay and protein estimation (in duplicate).

*Corresponding author:

Dr. M Mozammel Hoq, Professor, Department of Microbiology, University of Dhaka, Dhaka 1000, Bangladesh

Tel (Office): (02) 9661920-73/7734; Fax: +880 (02) 8615583; E-mail: mhoq@univdhaka.edu 
Estimation of extracellular soluble protein

Soluble protein in the culture supernatant was estimated according to the Bradford method ${ }^{7}$ using bovine serum albumin (BSA) as standard.

\section{Determination of keratinolytic protease activity}

Keratinolytic protease activity was measured by modified azocasein (Sigma, USA) digest method ${ }^{8}$. The enzyme (400 ml) was incubated with $200 \mathrm{ml}$ of $1 \%$ azocasein in $0.05 \mathrm{mM}$ Tris-HCl buffer (pH 8.5) at $37^{\circ} \mathrm{C}$ for $30 \mathrm{~min}$ in a shaking water bath. The reaction was terminated by adding $1.4 \mathrm{ml}$ of $10 \%$ trichloroacetic acid (TCA) and the mixture was kept at $4^{\circ} \mathrm{C}$ for $15 \mathrm{~min}$. After centrifugation at 10,000 rpm for $10 \mathrm{~min}, 1 \mathrm{ml}$ of the supernatant was decanted to a fresh tube and mixed with $1 \mathrm{ml}$ of $0.5 \mathrm{MNaOH}$. The absorbance of the reaction mixture was read at $440 \mathrm{~nm}$ against a control prepared in the same way, except that the TCA was added before addition of enzyme. One unit of enzyme activity was defined as an increase of 0.01 absorbance units per min under the given conditions.

\section{Results and Discussion}

The optimum incubation time for keratinolytic protease production by $B$. licheniformis MZK-03 was determined by carrying out the fermentation in 500-ml Erlenmeyer flask containing $95 \mathrm{ml}$ feather mill medium at $37^{\circ} \mathrm{C}$ and $150 \mathrm{rpm}$ in an orbital shaker. Samples were collected at 3-h interval up to $48 \mathrm{~h}$. Time course data revealed that maximum level of keratinolytic protease was produced after $42 \mathrm{~h}$ of cultivation period, which represented $95 \mathrm{U} / \mathrm{ml}$ enzyme activity and $0.28 \mathrm{mg} / \mathrm{ml}$ protein concentration (Figure 1). Protein concentration decreased with time while enzyme activity increased as feather mill consists of protein (keratin) that was hydrolyzed more with elapsed time. An initial peak of keratinolytic protease activity was observed at $21 \mathrm{~h}$ of the cultivation $(84 \mathrm{U} / \mathrm{ml})$. This could be explained by Type II fermentation where two maxima were observed (Figure 1). Other possible explanation would be cytoplasmic membrane bound longer secretion phase or the excretion of other proteases rather than primary protease ${ }^{9-10}$. It was reported previously that $B$. licheniformis PWD-1 exhibited maximum keratinolytic protease activity $(35 \mathrm{U} / \mathrm{ml})$ by azo-keratin method after $30 \mathrm{~h}$ of incubation period ${ }^{11}$.

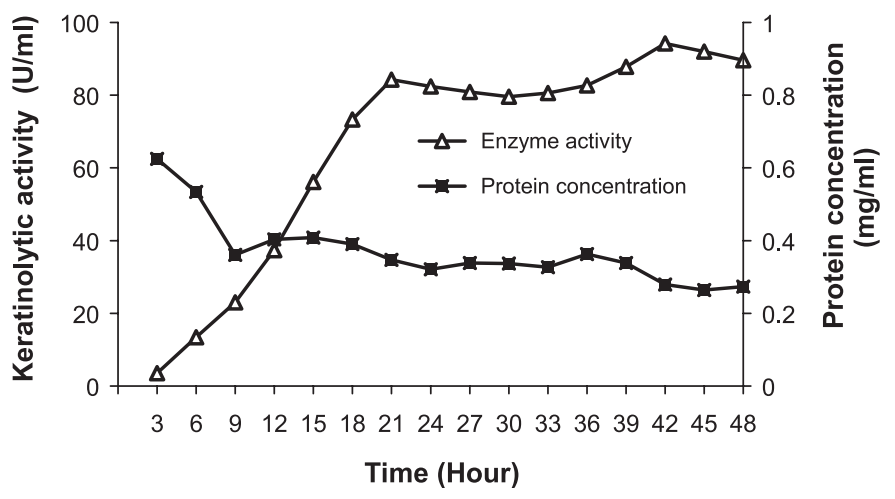

Figure 1. The time course of keratinolytic protease production by Bacillus licheniformis MZK-03.
The effect of different initial $\mathrm{pH}$ on the production of keratinolytic protease by B. licheniformis MZK-03 was investigated by adjusting the initial $\mathrm{pH}$ of feather mill broth to different $\mathrm{pH}$ ranging from 5.0 to 13.0 separately with $0.1 \mathrm{~N} \mathrm{HCl}$ and $1 \mathrm{NNaOH}$ in $500-\mathrm{ml}$ Erlenmeyer flask containing $95 \mathrm{ml}$ medium. It was found that the strain efficiently produced keratinolytic protease over a wide range of initial culture $\mathrm{pH}$ (5.0 to 12.0). The enzyme production was drastically reduced at $\mathrm{pH} 13.0$ that corresponded to the enzyme activity ca. $14 \%$ of the maximum (Figure 2 ) and high protein concentration.

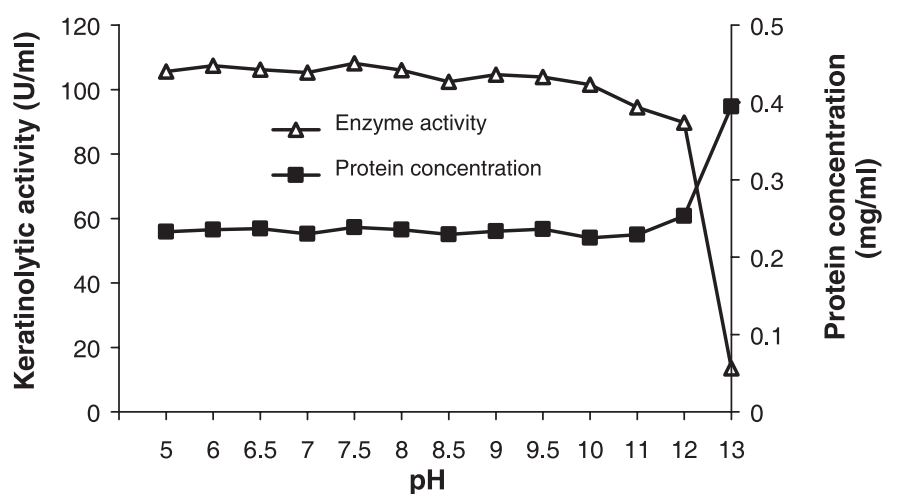

Figure 2. Effect of initial $\mathrm{pH}$ on keratinolytic protease production by Bacillus licheniformis MZK-03.

The effect of cultivation temperature on the production of keratinolytic protease by $B$. licheniformis was determined between $30^{\circ}$ and $50^{\circ} \mathrm{C}$ in an orbital shaker at $150 \mathrm{rpm}$ for $42 \mathrm{~h}$ as it is a mesophilic bacterium ${ }^{23}$. Keratinolytic protease production rate was highest $(96 \mathrm{U} / \mathrm{ml})$ at $37^{\circ} \mathrm{C}$, which was also been reported for the production of keratinolytic protease from other Bacillus isolates ${ }^{5,12}$.

The fermentation was carried out at different agitation rates ranging from 100 to $250 \mathrm{rpm}$ in an orbital shaker to find out the appropriate agitation rate for keratinolytic protease production. It exhibited a gradual increase of keratinolytic protease production with increased agitation rates (data not shown) and the production was maximum at $200 \mathrm{rpm}(109 \mathrm{U} / \mathrm{ml})$.

The optimum $\mathrm{pH}$ for keratinolytic protease activity was determined using substrate solutions prepared in different buffer systems $(0.05 M)$ like citrate-phosphate buffer (pH 5.0-6.0), phosphate buffer (pH 6.5-7.5), Tris-HCl buffer (pH 8.0-9.0), carbonate buffer (9.5-10.0) and glycine-NaOH buffer (11.0-13.0). Reaction mixtures were incubated at $40^{\circ} \mathrm{C}$ for $30 \mathrm{~min}$ and residual keratinolytic protease activity was measured. The enzyme showed maximum activity at $\mathrm{pH} 8.5$ and the activity was about $75 \%$ of that of the maximum over a wide range of $\mathrm{pH} 7.0$ to 9.5 (data not shown). Activity declined gradually with more alkalinity (at $\mathrm{pH} 11.0$, the activity was below 30\%) as well as in more acidic condition (at pH 6.0, activity was below 35\%). 
The $\mathrm{pH}$ stability of the keratinolytic protease was determined by pre-incubation of the enzyme in various buffers of different $\mathrm{pH}$ values (5.0 to 13.0 ). The enzyme was 10 -fold diluted in respective buffers and incubated in a $10^{\circ} \mathrm{C}$ cooler for $24 \mathrm{~h}$. Control was made by 10 -fold dilution of the enzyme with distilled water. Residual activity was measured taking control as $100 \%$ activity. The enzyme remained stable over a wide range of $\mathrm{pH}$ from 7.0 to 11.0 (data not shown). The result indicated that residual activity at $\mathrm{pH} 6.5$ and 12.0 were about 8 and $19 \%$ of the control, respectively and remained over $70 \%$ up to $\mathrm{pH}$ 11.0. Maximum stability of keratinolytic protease was found at $\mathrm{pH}$ 8.5. Therefore, the keratinolytic protease is not able to work efficiently in high alkaline condition with the association of chemicals used in the dehairing step. These findings are in accordance with several earlier reports showing $\mathrm{pH}$ optima of 9.09.5 of keratinase and proteases from other organisms ${ }^{13-15}$. A higher alkalinity of the protease produced by B. licheniformis MIR 29 has been reported having an optimum $\mathrm{pH}$ of $13.0^{16}$.

The optimum temperature for the keratinolytic protease activity was determined by incubating the reaction mixture at different temperatures ranging from $20^{\circ}$ to $50^{\circ} \mathrm{C}$ and assayed at $\mathrm{pH} 8.5$ for $30 \mathrm{~min}$. The optimum temperature for keratinolytic protease activity was recorded $37^{\circ} \mathrm{C}$ (data not shown). The activity was below 30\% at temperature $20^{\circ} \mathrm{C}$ and ca. $50 \%$ at $50^{\circ} \mathrm{C}$ recorded. The optimum temperatures of extracellular proteases produced by $B$. cereus MZK-09 and B. licheniformis S-40 were reported to be $40^{\circ} \mathrm{C}$ and $50^{\circ} \mathrm{C}$, respectively ${ }^{17-18}$.

The thermostability of keratinolytic protease was measured by incubating the enzyme preparation at different temperatures between $30^{\circ}$ to $70^{\circ} \mathrm{C}$ for different time intervals (10 to $60 \mathrm{~min}$ ). The activity at $40^{\circ} \mathrm{C}$ was considered as $100 \%$ and the residual activity was measured. Half-life of the enzyme at different temperatures was measured from the graph (Figure 3 ). The result showed that at temperature $60^{\circ}$ and $70^{\circ} \mathrm{C}$ the keratinolytic protease lost its activity rapidly and the half-life at $60^{\circ}$ and $70^{\circ} \mathrm{C}$ was 7 and $3 \mathrm{~min}$ respectively for the $B$. licheniformis MZK-03 enzyme. The enzyme was stable at $40^{\circ} \mathrm{C}$ for more than $3 \mathrm{~h}$ (Figure 3 ). The serine alkaline protease produced by $B$. subtilis PE-11 was reported to be $100 \%$ stable at $60^{\circ} \mathrm{C}$ after 350 min of incubation ${ }^{19}$.

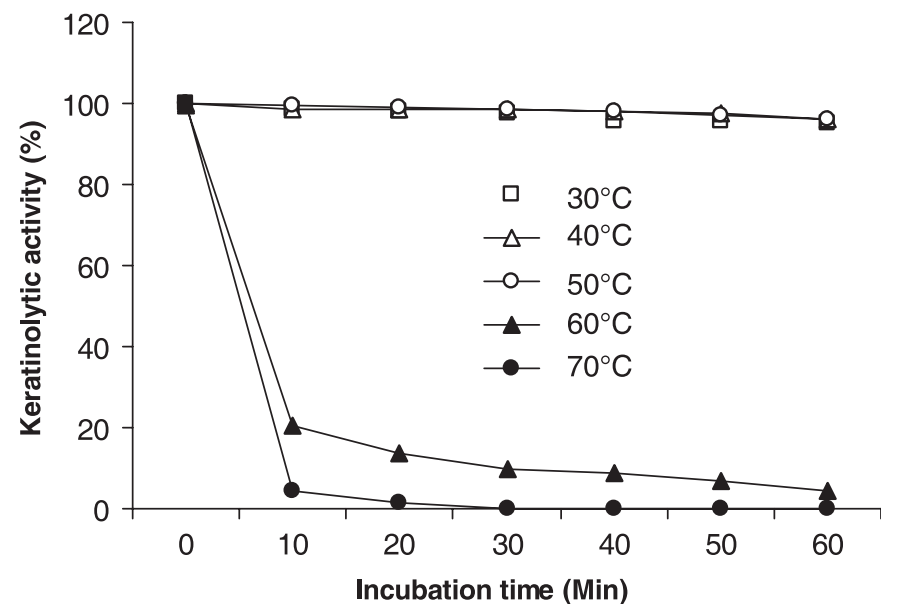

Figure 3. Determination of the temperature stability of keratinolytic protease.
The enzyme was dispensed in four 30-ml McCartney bottle and two were held at $4^{\circ} \mathrm{C}$ and others at $20^{\circ} \mathrm{C}$ to investigate the storage stability at those temperatures. Enzyme assay was performed every four days interval until the enzyme activity reached half of the initial enzyme activity. The keratinolytic protease was stable at $4^{\circ} \mathrm{C}$ for more than a month (Figure 4). Half-life of the keratinolytic protease from $B$. licheniformis MZK-03 at $20^{\circ} \mathrm{C}$ was about 20 days and at $4^{\circ} \mathrm{C}$ was about 34 days (Figure 4). Stability of keratinolytic protease at $20^{\circ} \mathrm{C}$ indicated that it could be used under ambient condition $\left(25^{\circ}-30^{\circ} \mathrm{C}\right)$ successfully.

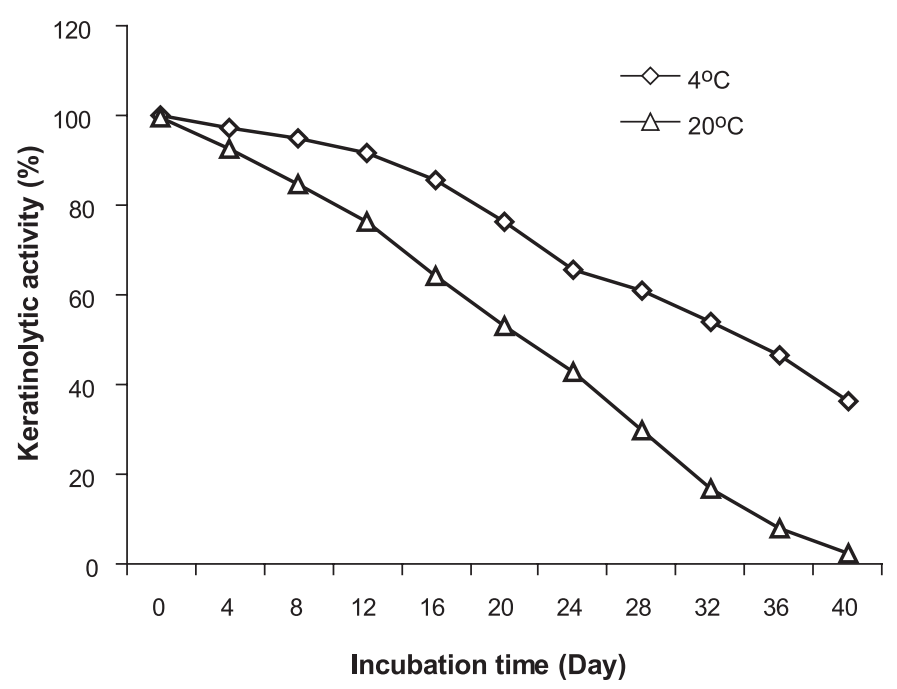

Figure 4. Effect of storage temperature on the keratinolytic protease.

With a view to increase the storage stability, investigation was carried out to observe the effect of different metal ions on keratinolytic protease. The effects of metal ions $\left(\mathrm{Ca}^{2+}, \mathrm{Mg}^{2+}\right.$, $\mathrm{Mn}^{2+}, \mathrm{K}^{+}, \mathrm{Cu}^{2+}$ and $\mathrm{Hg}^{2+}$ ) on the keratinolytic protease were investigated by adding the chloride salt of those metal ions with enzyme at concentrations of 1,5 and $10 \mathrm{mM}$. Relative enzyme activities were measured considering the control (enzyme mixed with distilled water at respective quantity) as $100 \% . \mathrm{Mg}^{2+}, \mathrm{Mn}^{2+}$, $\mathrm{Ca}^{2+}$ and $\mathrm{K}^{+}$did not have any remarkable effect on the keratinolytic activity whereas $\mathrm{Hg}^{2+}$ and $\mathrm{Cu}^{2+}$ inhibited the enzyme activity.

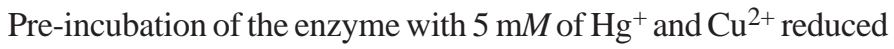
the activity by 62 and $25 \%$ respectively (data not shown). These results correlate with other related studies on proteases where $\mathrm{Mg}^{2+}, \mathrm{Ca}^{2+}$ and $\mathrm{Mn}^{2+}$ increased their activity by 16,35 and $8 \%$, respectively, and $\mathrm{Hg}^{2+}$ reduced the activity by $7 \% 19$. In case of $\mathrm{Hg}^{2+}$, the reduction of the enzyme activity can be attributed to its affinity with the two -SH group present in the keratinolytic protease and disrupt the native polypeptide structure ${ }^{20}$.

Inhibition studies primarily give an insight into the nature of an enzyme, its cofactor requirements, and the nature of active centre $^{21}$. The effect of inhibitors like phenylmethylsulfonyl fluoride (PMSF) and ethylene diamine tetra acetic acid (EDTA) on the keratinolytic protease produced from B. licheniformis MZK-03 was investigated. Inhibitors were mixed with crude enzyme at various concentrations 10,5 and $1 \mathrm{mM}$. The mixer was incubated 
at $10^{\circ} \mathrm{C}$ for $24 \mathrm{~h}$. Control was made by mixing respective amount of distilled water with crude enzyme. PMSF (10 mM) inhibited the keratinolytic protease activity by $80 \%$ (data not shown). It has been reported that PMSF combines with the essential serine residue in the active site of proteases and results in a complete loss of enzyme activity ${ }^{22}$. This result, therefore categorizes the keratinolytic protease produced by B. licheniformis MZK-03 as a serine protease. However, many Bacillus isolates are known to produce alkaline serine protease $\mathrm{e}^{23}$. The presence of EDTA could also inhibit the keratinolytic protease activity partially (<30\%).

The effects of various tannery chemicals on the activity of different commercial enzymes and the crude keratinolytic protease from $B$. licheniformis MZK-03 were examined. Solutions of tannery chemicals were mixed with enzyme preparations in a concentration likely to be used in different stages of hide processing [0.35\% $\mathrm{Na}_{2} \mathrm{CO}_{3}, 0.02 \%$ Na-hypochlorite, $2 \% \mathrm{CaO}$, $2 \% \mathrm{Na}_{2} \mathrm{~S}$ and $2.5 \%\left(\mathrm{NH}_{4}\right)_{2} \mathrm{SO}_{4}$ ] and the resultant $\mathrm{pH}$ was detected. After incubation, enzyme activity was measured at different time intervals. It was observed that commercial enzymes from NOVO (England) and the crude keratinolytic protease were completely unstable in presence of $\mathrm{CaO}$ and $\mathrm{Na}_{2} \mathrm{~S}$ while about $50 \%$ of their activities were retained in $\mathrm{Na}_{2} \mathrm{CO}_{3}$, Na-hypochlorite and were completely unaffected with $\left(\mathrm{NH}_{4}\right)_{2} \mathrm{SO}_{4}$ (Figure 5). Incompatibility of enzyme with lime-sulphide may be due to high alkaline condition ( $\mathrm{pH}>13.0$ ) when the enzymes' net electric charge might be changed along with subsequent modifications in its threedimensional structure. On the other hand the stabilization effect of ammonium sulphate suggested that it might be used as a stabilizer in enzyme preservation. One of the commercially available enzymes was supplemented with ammonium sulphate (i) Compatibility of crude keratinase

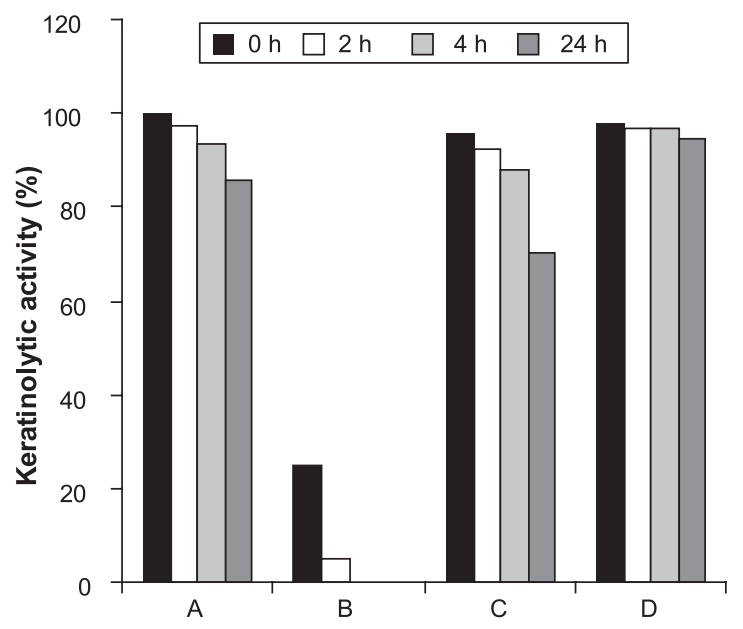

(iii) Compatibility of enzyme (England)

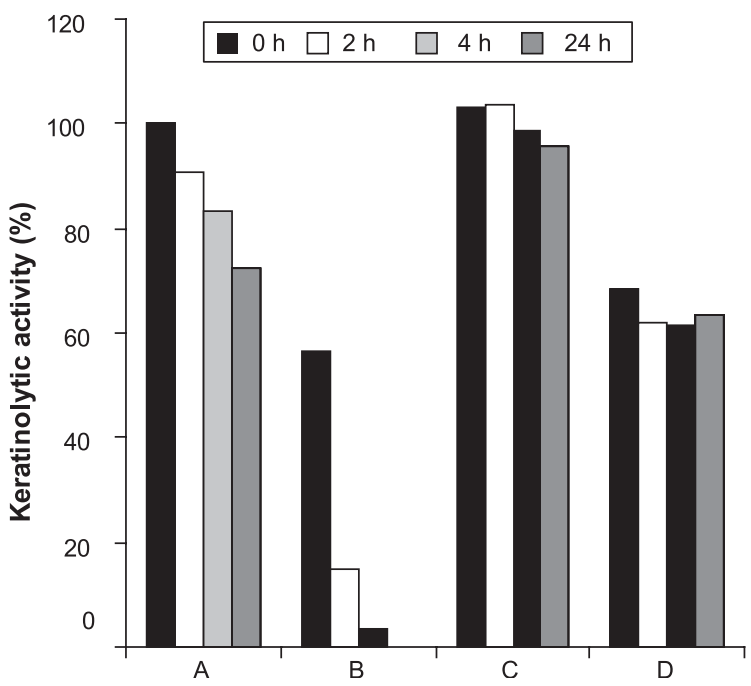

(ii) Compatibility of NOVO

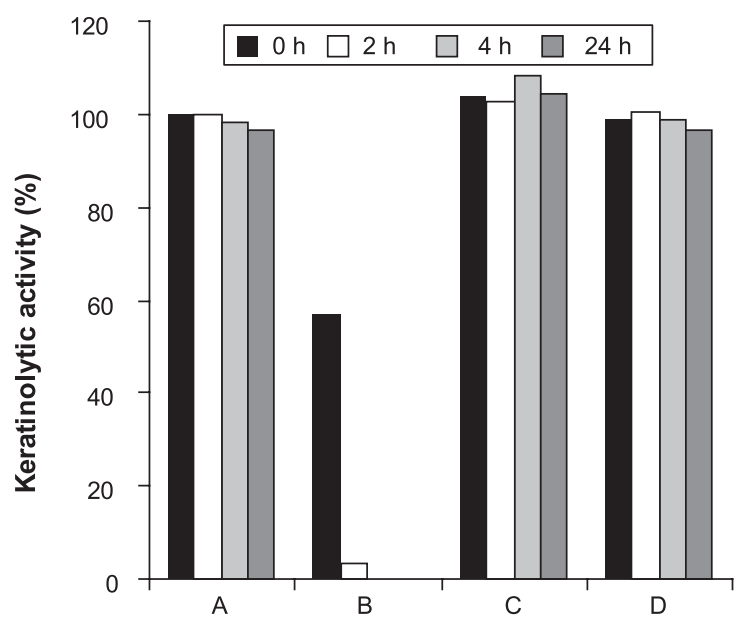

(iv) Compatibility of commercial enzyme

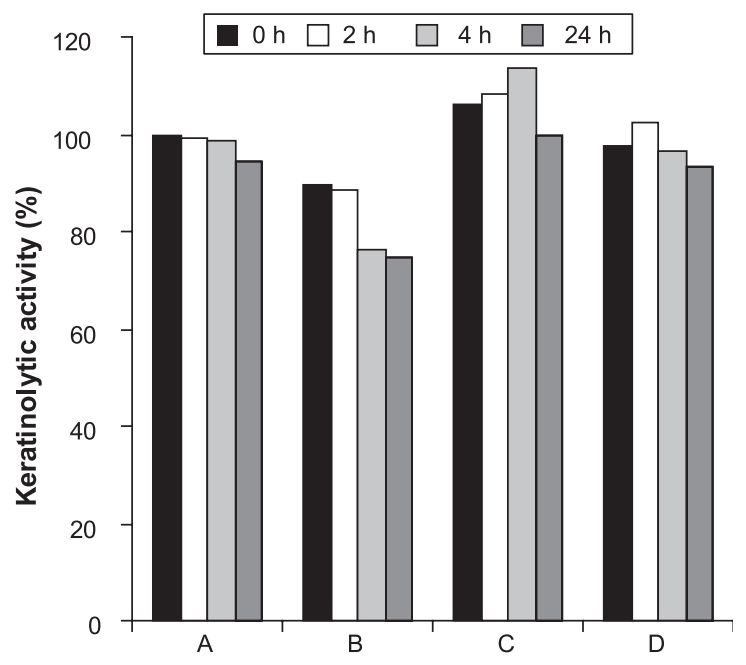

Figure 5. Compatibility test of keratinolytic protease and commercial tannery enzymes with different tannery chemicals. $\mathrm{A}=$ Enzyme $\mathrm{B}=$ Enzyme $+\mathrm{Na}_{2} \mathrm{~S}+\mathrm{CaO} ; \mathrm{C}=$ Enzyme $+\mathrm{Na}_{2} \mathrm{CO}_{3} ; \mathrm{D}=$ Enzyme $\left.+\left(\mathrm{NH}_{4}\right)_{2} \mathrm{SO}_{4}\right)$ 
and it remained stable under high alkaline condition in presence of lime-sulphide.

The remarkable high production ability of keratinolytic protease by $B$. licheniformis MZK-03 validates the potential of using this strain in industries for large scale production of the enzyme. The broad $\mathrm{pH}$ stability (6.0-11.0) of the produced enzyme provides some advantages of using in many industrial processes. Its stability under ambient condition for few weeks allows it to be used and stored in crude form under limited facilities. The use of $\left(\mathrm{NH}_{4}\right)_{2} \mathrm{SO}_{4}$ as stabilizing agent provided a viable mechanism of increasing the storage stability of the enzyme which can make the enzyme more compatible with the commercially available chemicals used in tannery industry under high alkaline condition.

\section{Acknowledgement}

This work was supported by the Ministry of Science and Information \& Communication Technology, Government of the People's Republic of Bangladesh.

\section{References}

1. Rao MB, Tanksale AM, Ghatge MS \& Despande VV. 1998. Molecular and biotechnological aspects of microbial proteases. Microbiol Mol Biol Rev. 62(3): 597-635.

2. Onifade AA, Al-Sane NA, AL-Musallam AA \& Al-Zarban S. 1998. A review: Potentials for biotechnological applications of keratindegrading microorganisms and their enzymes for nutritional improvement of feathers and other keratins as livestock feed resources. Bioresource Technol. 66(1): 1-11.

3. Ichida JM, Krizova L, LeFevre CA, Keener HM, Elwell DL \& Burtt Jr EH. 2001. Bacterial inoculum enhances keratin degradation and biofilm formation in poultry compost. J Microbiol Methods. 47: 199-208.

4. Singleton P \& Sainsbury D. 1987. Dictionary of Microbiology and Molecular Biology, $2^{\text {nd }}$ edn, pp 80-81. John Wiley, Chichester.

5. Hoq MM, Siddiquee KAZ, Kawasaki H \& Seki T. 2005. Keratinolytic activity of some newly isolated Bacillus species. J Biol Sci. 5(2): 193-200.

6. Griffin HL, Greene RV \& Cotta MA. 1992. Isolation and characterization of an alkaline protease from the marine shipworm bacterium. Curr Microbiol. 24: 111-117.

7. Bradford MM. 1976. A rapid and sensitive method for the quantitation of microgram quantities of protein utilizing the principle of proteindye binding. Appl Microbiol Biotechnol. 72: 248-254.

8. Gradisar H, Kern S \& Friedrich J. 2000. Keratinolytic protease of Doratomyces microsporus. Appl Microbiol Biotechnol. 53(2): 199200.
9. Kurnet J. 1992. Effect of reducing agents on the proteolytic activity of enzymes of Microsporum gypseum. Mycoses. 35: 343-348.

10. Malviya HK, Rajak RC \& Hasija SK. 1992. Synthesis and regulation of extracellular keratinolytic protease in three fungi isolated from the grounds of a gelatine factory, Jabalpur, India. Mycopath. 330: 1-4.

11. Cheng SW, Hu HM. \& Shen SW. 1995. Production and characterization of keratinolytic protease of a feather degrading Bacillus licheniformis PWD-l. Bioscience. Biotechnol Biochem. 59(12): 2239-2243.

12. Taha IZ. 1998. Cloned Bacillus subtiliss alkaline protease (apr A) gene showing high level of keratinolytic activity. J Appl Biotcchnol Biochem. 70-72: 199-205.

13. Malathi S \& Dhar SC. 1987. Production of extracellular protease by an Aspergillus flavus isolate and its application in the depilation of skins. Leather Science. 34: 67-76.

14. Manachini PL \& Parini C. 1988. Thermostable alkaline protease produced by Bacillus thermoruber - A new species of Bacillus. Appl Microbiol Biotechnol. 28: 409-413.

15. Kurnet J. 1989. Biochemical mechanism of keratin degradation by the actinomycetes Streptomyces fradiae and the fungus Microsporum gypseum: A comparison. J Biol Microbiol. 29: 597-604.

16. Ferrero MA, Castro GR, Abate CM, Baigori MD \& Sineriz F. 1996. Thermo stable alkaline protease of Bacillus licheniformis MIR 29: Isolation, production and characterization. Appl Microbiol Biotechnol. 45: 327-332.

17. Hossain MS, Iqbal MS and Hoq MM. 2004. Fermentative characteristics of alkaline protease by Bacillus cereus MZK-09. Bangladesh J Microbiol. 21: 86-89

18. Sen S \& Saytyanarayana T. 1993. Optimization of alkaline protease production by Bacillus licheniformis S-40. J Ind Microbiol. 33: 4347.

19. Kunamneni A, Poluri E \& Davuluri SP. 2003. Purification and partial characterization of serine alkaline protease from newly isolated Bacillus subtilis PE-11. J Indian Biotechnol. 17: 101-103.

20. Michael J. Pelczer JR, Chan ECS \& krieg NR. 1986. Control by chemical agents. In Microbiology (Martin JM ed), pp 497. McGrawHill Book Co, Singapore.

21. Sigma DS \& Mooser G.1975. Chemical studies of enzyme active sites. Annu Rev Biochem. 44: 889-931.

22. Gold AM \& Fahrney D. 1964. Sulfonyl fluorides as inhibitors of esterases II. Formation and reactions of phenylmethane sulfonyl alpha-chymotrypsin. Biochem. 3: 783-791.

23. Priest GF, Goodfellow M \& Todd C. 1988. A numerical classification of the genus Bacillus. J Gen Microbiol. 134: 1847-1882. 